\title{
THE DIVERSITY AND CONSERVATION STATUS OF SNAKES IN RAWA MEKAR JAYA, RIAU, INDONESIA
}

\author{
Agung Purnomo Adjie ${ }^{1}$, Sri Catur Setyawatiningsih ${ }^{2 *}$
}

Received : October 04, 2020

Accepted : September 01, 2021

DOI: 10.15575/biodjati.v6i2.9462

${ }^{1,2}$ Department of Biology, Faculty of Mathematics and Natural Sciences, Universitas Riau, Kampus Binawidya Km 12,5 Simpang Baru, Pekanbaru 28293

e-mail:

1.apurnomo1803@gmail.com

*2sri.catur@lecturer.unri.ac.id

*Corresponding author

\begin{abstract}
Snakes in Mekar Jaya mangrove ecosystem have the potential be ecotourism objects. On the other hand ecotourism activities might reduce the quality of wildlife habitat, including that of the snake. This study aimed to determine the diversity and status of snake species in the mangrove ecosystem of Rawa Mekar Jaya. A transect of $20 \times 50 \mathrm{~m}$ was made in three stations: rivers (S1), ecotourism route (S2), and dense mangroves (S3). The observation was carried out at low tide and repeated three times with a span of 2 days. Snake data was collected using the Visual Encounter Survey (VES) method. We revealed 59 snakes in the mangrove area of Rawa Mekar Jaya consisting of 3 species namely Boiga dendrophila, Cerberus rynchops, and Trimeresurus purpureomaculatus. B. dendrophila and C. rhyncops are mangrove specialists. The Shannon Wiener diversity index value $\left(H^{\prime}\right)$ for all observation stations is below one, so it is classified as low. All types of snakes found are not protected and classified as the least concern. C. rynchops is included in the CITES appendix III
\end{abstract}

Keywords: mangrove specialist, arboreal snake, semi-aquatic snake, ecotourism attraction

\section{Citation}

Adjie, A. P. \& Setyawatiningsih, S. C. (2021). The Diversity and Conservation Status of Snakes in Rawa Mekar Jaya, Riau, Indonesia. Jurnal Biodjati, 6(2), 246-254.

\section{INTRODUCTION}

Snakes are poikilotherm animals that belong to the suborder of Serpentes (O'Shea, 2018). Snakes are feared by society because they are considered dangerous for humans as some species of snakes have venom that can kill in a matter of minutes. On the other hand, snakes also have many benefits for humans such as pest control agents for insects and rats, they can also be kept as pets; serve as raw materials for the leather industry and traditional medication, and are an additional attraction for ecotourism (Partasasmita et al., 2016; Asri \& Yanuwadi, 2015; Imron et al., 2018).
Rawa Mekar Jaya is one of the mangrove ecotourism areas in Riau. This ecotourism presents the unique roots of natural mangrove forests that are often used as photographic spots. Besides being an ecotourism area, The Rawa Mekar Jaya mangrove is also the habitat for faunas, including snakes. The existence of snakes in this ecotourism location is an additional value for ecotourism to be used as a medium of environmental education, by discussing the role of snakes in the mangrove ecosystem. Arboreal snakes are snakes that usually bask in the roots or branches of mangrove vegetation. The data about types of snakes that exist in Rawa Mekar Jaya mangrove ecosystems are not available yet. 


\section{JURNAL BIDDJATI}

http://journal.uinsgd.ac.id/index.php/biodjati

Data on the snake diversity and their status in Rawa Mekar Jaya mangroves are necessary for the management of ecotourism in the future, thus this study aimed to determine the diversity and status of snake species in the mangrove ecosystem of Rawa Mekar Jaya. Therefore people can learn more about the species and know how to deal with the snake population without killing the creatures (Kurniawan et al., 2017).

\section{MATERIALS AND METHODS}

\section{Study Area}

This study was conducted on 20-28 January, 2020, covers an area of \pm 25 hectares of Rawa Mekar Jaya mangrove forest, Rawa Mekar Jaya Village, Sungai Apit District, Siak Regency, Riau Province (Figure 1). This study area was divided into three stations. Station 1 (S1) was located on the river bank with a distance of $0-10 \mathrm{~m}$. This station has a mud substrate and is rarely traversed by humans, the vegetation is tight, especially on the riverbanks. At this location, there are many crab holes which also serve as hiding places for C. rynchops snakes. Station 2 (S2) was located inside the forest. There's an ecotourism access route in the form of a wooden board, thus the vegetation is not too dense as some of it has been cut down to make access routes. The station is $30-40 \mathrm{~m}$ from the river, with a fairly hard muddy substrate.. Station 3 (S3) was located in a dense mangrove forest, rarely traversed by humans, with a muddy substrate. This station is quite far from the river, with a distance of $40-50 \mathrm{~m}$. The vegetation in this location is tighter than the other two stations because this station is used as a conservation area. The vegetation that dominates all stations are red mangroves (Rhizophora apiculata) and white mangroves (Rhizophora mucronata), as well as some Nipah trees (Nypa fructicans). The highest tide distance was about $50 \mathrm{~m}$.

\section{Data Collection and Identification}

At each station, a transect measuring $20 \mathrm{mAt}$ each station, a transect of $20 \mathrm{~m} \times 50$ m (modified from Budiada et al., 2017) was constructed and placed in a location assumed to be a snake's nest or hiding places, such as tree branches, roots, puddles, tree holes, or river banks. Observations were carried out by the Visual Encounter Survey (VES) method. The VES is a standard method for determining the species richness and relative abundance

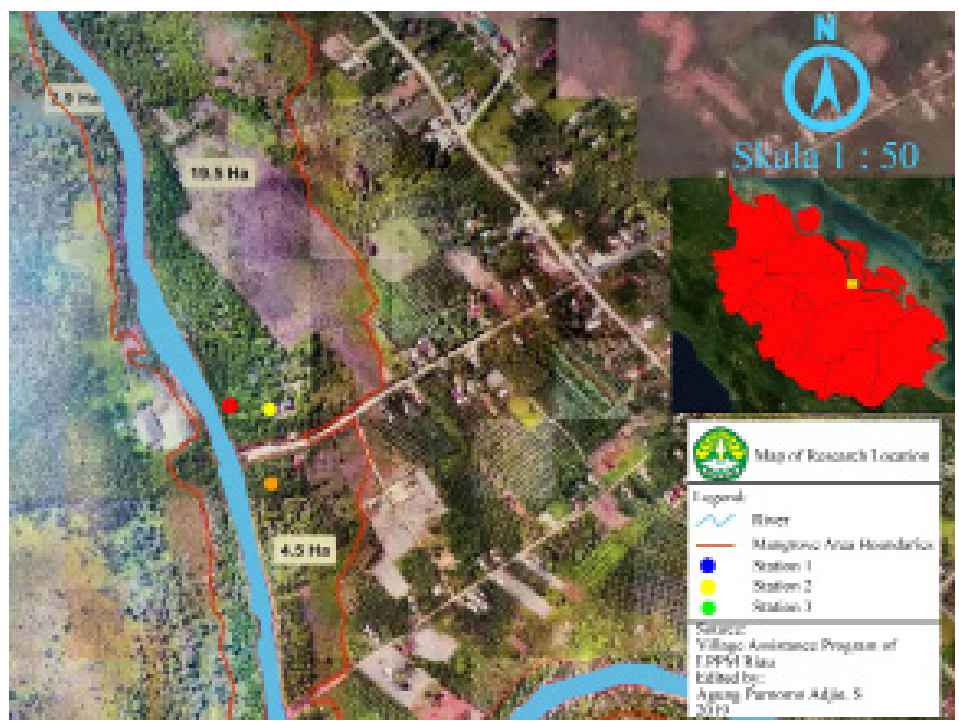

Figure 1. Map of research location 


\section{JURNAL BIDDJATI}

http://journal.uinsgd.ac.id/index.php/biodjati

of reptile species (including snakes) in an area (Kamsi, 2018). Observations were often done by foot at low tide along the transect line in the morning from 07.00 am to 10.00 am and at night from $07.00 \mathrm{pm}$ to $10.00 \mathrm{pm}$. Observations were repeated 3 times with a span of 2 days. There were 6 observers (modified from Hidayah, 2018).

Snakes were caught by grab sticks and snake hooks. In case iff it was not possible to catch them with these tools (especially for highly venomous snakes), snakes were captured by a camera, and the number of individuals was recorded on each transect. Identification of the snake was was referredto several books, namely $107^{+}$Snake Indonesia (Marlon, 2014), Amfibi \& Reptil Kawasan Hutan Batang Toru (Kamsi et al., 2017), and The Book of Snakes A Life-Size Guide to Six Hundred Species from Around the World (O'Shea, 2018), as well as some of the most recent journals on snakes. The names of the observed snakes followed the reptile-database.org. In addition, several environmental parameters (temperature, humidity) of mangroves were measured in situ. Measures of environmental factors were conducted with snake observation.

The numbers of snake data in each station and environmental parameters were tabulated in the chart. The type of snake obtained was described. Snake diversity on each transect was calculated using the Shannon Wiener diversity index. The level of diversity of snakes at the study location was categorized into three, namely: (a) $\mathrm{H}^{\prime}<1$, low diversity level of snakes; (b) $1<\mathrm{H}^{\prime}<3$, medium diversity of snakes is moderate, and (c) $\mathrm{H}^{\prime}>3$, high diversity of snakes (Wilhm \& Dorris 1968).

The national conservation status of each species was checked based on national regulation

(P.106/MENLHK/SETJEN/
Kum.1/6/2018). Meanwhile, international regulation conservation status based on the status of extinction referred to the International Union for the Conservation of Nature and Natural Resources (IUCN) Red List / www.iucnredlist.org. The trade status of snakes obtained in the study referred to the Convention on International Trade in Endangered Species (CITES)/ www.cites. org.

\section{RESULTS AND DISCUSSION}

\section{Snake Species Richness}

In this research, 59 individual snakes were found. These snakes belong to three species: Boiga dendrophila, Cerberus rynchops, and Trimeresurus purpureomaculatus (Figure 2). B. Dendrophila and C. rynchops are closely related to the mangrove ecosystem or are known as a "mangrove specialists" (O'Shea 2018). While T. purpureomaculatus is known as mangrove viper snake or shore pit viper (Mong \& Tan, 2016).

$B$. dendrophila belongs to the Colubridae family (Figure 2a). The body length can reach up to $2.5 \mathrm{~m}$. The shape of the head is long and rounded; the eyes are oval, large, protruding, flank; the nostrils are quite large. The basic color of the dorsal is pitch black with a golden yellow outline around the body, hence it is known locally as the golden ring snake. This ring color pattern only extends to the pelvis. This snake uses its tail, tapered tails to wrap around tree branches and twigs so it is known to be arboreal. During the day, $B$. dendrophyla species is found on tree branches for sunbathing, and in wooden huts waiting for preys. In additionto mangrove ecosystems, this species is also found in lowland forests and peat swamps (Das, 2015).

C. rynchops species is known as pond 


\section{JURNAL BIDDJATI}

http://journal.uinsgd.ac.id/index.php/biodjati

snake (Figure $2 b$ ). Its head is a long triangle with a slightly blunt tip, its eyes round, small, and slightly protruding; it has nostrils, located above the muzzle, there is a black line from behind the eyes to the neck. Its body is cylindrical, with a long tapered tail that makes it easy to move in the mud. The dorsal part of the body is basic gray with brown, circular, or semicircular regular patches from head to tail. The ventral part is bony white. These snakes are found on the banks of rivers, in puddles, and in mangrove mud. When found, the snake's head was above the water while waiting for prey. This snake is active at night (nocturnal). During the day, it usually hides in the crab hole.

T. purpureomaculatus is known locally as the mangrove snake or mangrove viper (Figure 2c). It has a large triangle with a slightly tapered tip head; slightly protruding oval, small, with vertical slit-like pupils eyes located on the upper side; nostril position is closer to the eyes. The background color of the dorsal body is olive to dark purplishbrown. The color of ventral body is bony white/cream with black patches. This snake has a long tail to wrap around the tree. These snakes are active at night, but during the day they usually bask on the branches and roots of mangroves.

The three types of snakes found in this study were classified as venomous snakes with different levels of venom. C. rynchops is low in venom so it is harmless to humans (Das, 2015). B. dendrophila is moderately venomous, but it rarely injects venom. This snake venom can only kill its prey while not too dangerous for humans (Pawlak et al., 2006). T. purpureomaculatus has high venom and its bite can cause death, so it is classified as a dangerous snake including for humans.

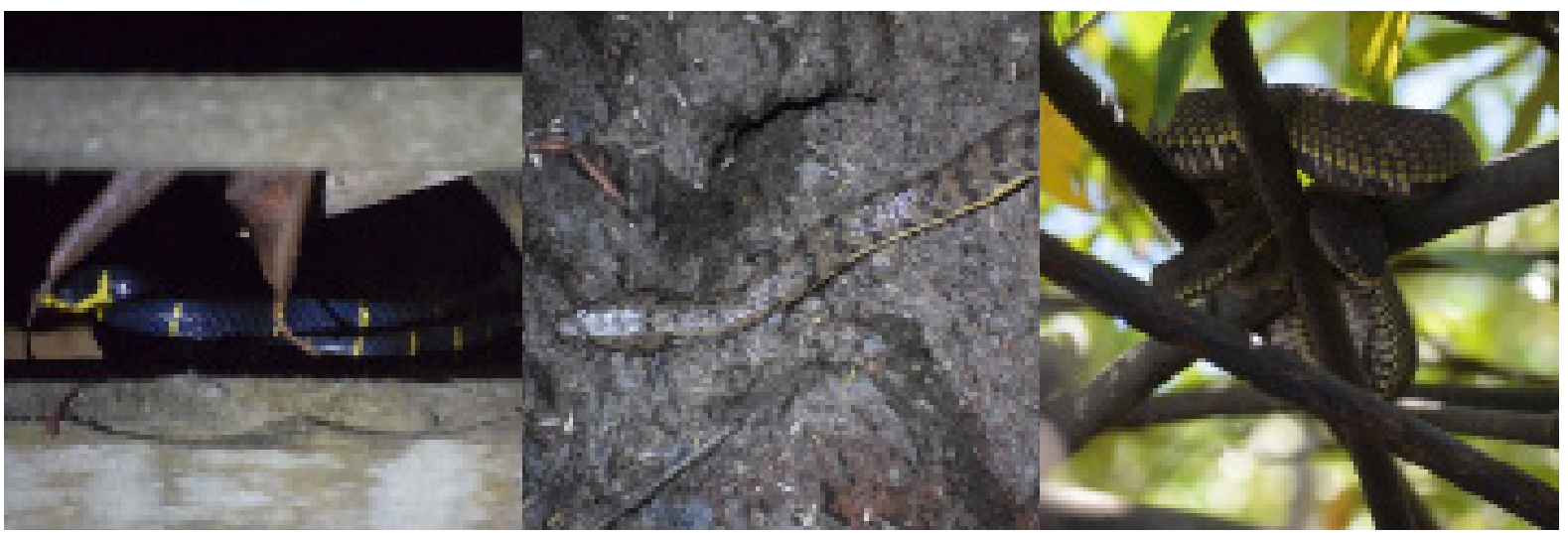

Figure 2. The composition of snake species found, (a) B. dendrophila, (b) C. rynchops, (c) T. purpureomaculatus

In general, the number of snake species found in the Rawa Mekar Jaya mangrove forest is still in the range of that mangrove snakes found elsewhere. The results of previous research the mangrove areas recorded a number of snakes ranging from one to four species in each area with a total of eight species. These species are C. rynchops, B. dendrophila, T. purpureomaculatus, Malayopython reticulatus, Acrochordus granulatus, Ptyas cf. mucosus, Laticauda colubrina, Fordonia leucobalia (Hernowo et al. 2007, Kurniawan et al. 2017, Kurniawan et al. 2018, Pratiska et al. 2017, Susanto et al. 2016, Yuliana et al. 2019). The small number of snake species present in each location is related to the unique and specific environmental conditions in the mangrove ecosystem, such as the influence of periodic tides. 


\section{JURNAL BIDDJATI}

http://journal.uinsgd.ac.id/index.php/biodjati

\section{The Mangrove Snakes Abudance}

This study succeeded in identifying three species of snakes. The number of individuals for each type of snake was different among stations (Figure 3), so their abundance was different. $B$. dendrophila and $C$. rynchops were found at all stations. Meanwhile, T. purpureomaculatus snakes were only found at two stations, namely S1 and S3.

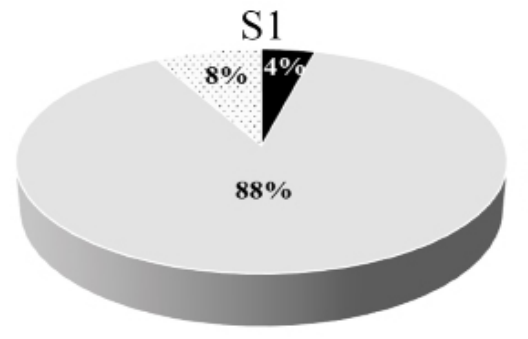

- Boiga dendrophila

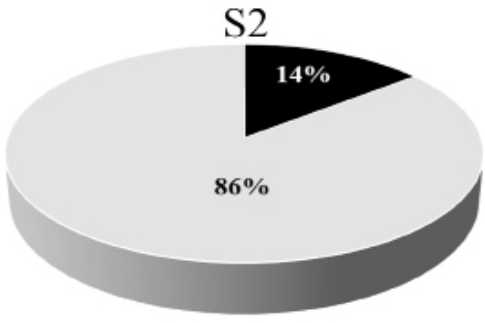

Cerberus rynchops
In general, C. rynchops was found mostly in three stations. The presence of this species can be highly abundant in wetlands, including mangrove ecosystems (Chim \& Diong, 2013). The main factor of the dominant number of this snake might be caused by the abundant availability of prey, such as the shoot fish (Periophthalmus sp.), which according to Das (2015), is the main prey for $C$. rynchops. In addition, the

Figure 3. Percentage of the abundance of the type of snake found in Rawa Mekar Jaya mangroves based on the station

C. rynchops snake is a semi-aquatic snake and is thought to have a fairly wide adaptation to tides. During its juvenile phase, C. rynchops were present in stagnant water, presumably because the microhabitat provided a hiding place and a source of food such as small fish. C. rynchops activity is influenced by tides. This snake will come out of hiding at high tide (Kurniawan et al., 2018).

$B$. dendrophila was found mostly in ecotourism stations (S2). Two assumptions, first, the presence of abundant prey is thought to increase the presence of predators (Durso et al., 2013) . Many rats were found hanging around during thenightobservations, andmany lizards were seen during the day observations. The presence of rats and lizards as prey for $B$. dendrophila in S2 is thought to increase the number of $B$. dendrophila individuals (Das, 2015). Second, the absence of a competitor, namely T. purpureomaculatus, is presumed to cause $B$. dendrophila found more in the ecotourism station. Marlon (2014) stated that $B$. dendrophila and T. purpureomaculatus shared the same type of prey so both species were potential competitors.

T. purpureomaculatus species was found in dense mangrove cover and rarely has human activity. This snake likes a habitat with dense vegetation cover making it easier for them to move from one tree to another. Kurniawan et al. (2017) stated that these species were found in the Avicennia marina with an elevation of $0.5 \mathrm{~m}$ above ground level. A. marina is a suitable habitat for $T$. purpureomaculatus because it provides a place to rest, hide and sunbathe on branches with a height of $0.5 \mathrm{~m}$. T. purpureomaculatus was not found at station 2 (S2) as this station is anecotourism route so that the mangrove cover was less dense. 


\section{JURNAL BIDDJATI}

http://journal.uinsgd.ac.id/index.php/biodjati

\section{Snake Diversity Index}

The value of the Shannon-Wiener diversity index for snake species in the mangrove area of Rawa Mekar Jaya was very low at less than 1 (Figure 4), while the species uniformity value was moderate ranging from $0.4-0.6$. This is presumably because the mangrove ecosystem is unique therefore only certain snakes can survive in the mangrove ecosystem (Cromsigt et al. 2009).

\section{Snake Conservation Status and its Impli- cation}

None of the snakes found in this study was protected according to P.106/MENLHK/ SETJEN/KUM.1/6/2018 attachment. This indicates that the snakes found at the research location are still widely distributed in nature. Based on the IUCN red list, all species of snakes found are in the low-risk category (Least Concern/LC), indicating these species are not yet the focus of species conservation.

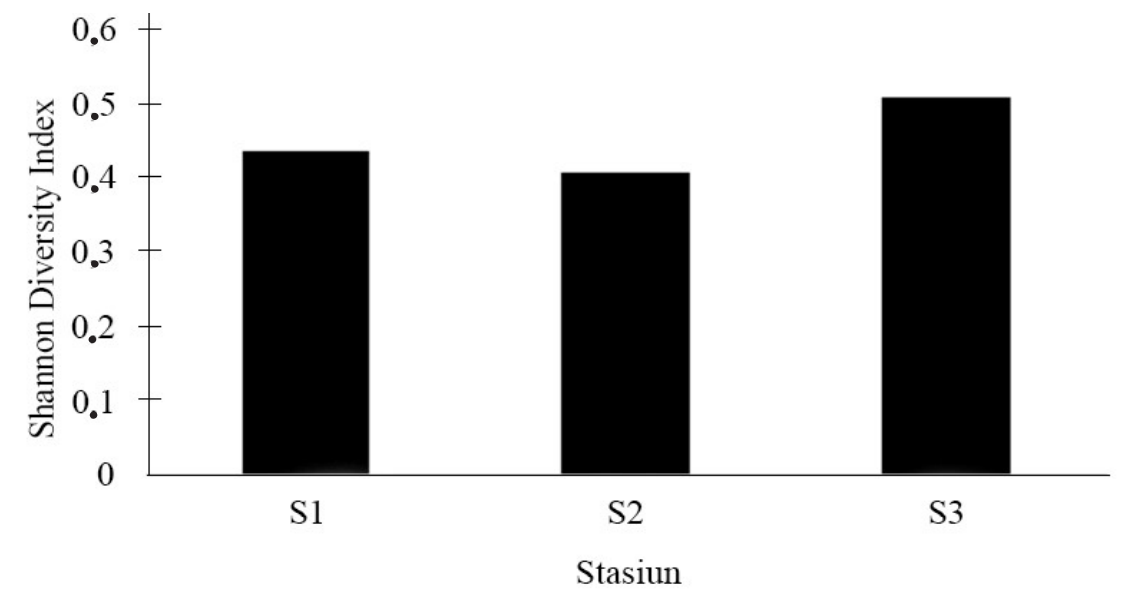

Figure 4. Diversity (H') and Equality (E) of snake species found

Based on Convention on International Trade in Endanger Species (CITES), only $C$. rynchops species is included in the appendix III category. This means, based on the country, it falls under the rare category so that the use of these species needs to be monitored internationally to prevent illegal exploitation (CITES, 1983). Utilization of these species is still allowed under a permit from the Natural Resources Conservation Agency/BKSDA.

The presence of snakes in the tourist area is like a two-edged sword. On the one hand, snakes can become a potential object of ecotourism (Imron et al., 2018), in other words, the presence of snakes while sunbathing in the afternoon can be an object of interest to mangrove tourists, especially students. For example, the presence of $B$. dendrophila in the Mangrove Forest ecotourism route in Rawa Adjie \& Setyawatiningsih
Meka Jaya Village can attract tourists because this species has a contrast color, black with a striking yellow band. According to Roza et al. (2018), the community can provide environmental/ conservational education on the uniqueness and benefits of snakes in the mangrove ecosystem to tourists. Sunbathing snakes tend to be less aggressive and prefer to stay quiet to stay safe.

On the other hand, the existence of $B$. dendrophila in the eco-tourism area is certainly a threat to visitors. B. dendrophila is a medium-venomous snake which bite can have quite serious effects. This requires education, for example in the form of a board informing the snakes found along the stroll with a brief description that is posted on the ecotourism route to keep visitors cautious. The local society can also be tour guides to 


\section{JURNAL BIDDJATI}

http://journal.uinsgd.ac.id/index.php/biodjati

accompany tourists to avoid the dangers of snakes. Ashas been done by the society in Bandar Bakau Dumai Village who have the awareness of conservational action, they do not kill snakes without the right reasons (Kurniawan et al., 2017). They name $T$. purpureomaculatus species "venomous Ulo Bakau". People report that these snakes avoid the tide by climbing higher branches or twigs of trees or entering houses or guard posts for ecotourism. When that happens, people would only take the snakes to a safe area. Kurniawan et al. (2017) stated that snakes are not aggressive and only attack when they feel provoked. Good support from the keepers, society, and tourists are needed to maintain the existence of snakes so that the mangrove ecosystem can be maintained in the future. Humans must get used to living side by side with snakes because snakes live in the human environment. Avoid killing snakes as much as possible, because snakes have ecological services as in they can be natural predators for pest animals such as insects and rodents (Asri \& Yanuwiadi, 2015).

Based on the results obtained during the study, it can be concluded that there are 59 individual snakes in the Rawa Mekar Jaya mangrove area consisting of three species, namely $B$. dendrophila, $C$. rynchops, and $T$. purpureomaculatus. The Shannon-Wiener diversity index $\left(\mathrm{H}^{\prime}\right)$ value of snakes at the three observation locations was low. All species of snakes found were classified as unprotected and the least concerned. Only C. rhyncops species is classified into CITES appendix III. This research is expected to provide preliminary data on the diversity of snakes in the Rawa Mekar Jaya mangrove. Therefore, it is also expected that future research can be focused on mangrove fauna diversity to determine the quality of mangroves.

\section{ACKNOWLEDGEMENTS}

Our gratitude is extended to the Head of Rawa Mekar Jaya Village and the manager of Rawa Mekar Jaya Mangrove Ecotourism who has allowed us to carry out this research. We also thank Binar Robinson Manurung, Muhammad Aldi Pratama Alfian Khusein, Refo Indra Thamrin, Savanna Zafira, and Khairani Latifa Malfi's who have helped us in collecting data in the field. Also, we thank Fidia Hudzaifah Akmal who helped us in this writing.

\section{REFERENCES}

Asri, A. S. K. \& Yanuwiadi, B. (2015). Persepsi Masyarakat Terhadap Ular sebagai Upaya Konservasi Satwa Liar Pada Masyarakat Dusun Kopendukuh, Desa Grogol, Kecamatan Giri, Kabupaten Banyuwangi. Indonesian Journal of Environment and Sustainable Development, 6(1), 42-47.

Budiada, I. G. M. A. H. (2017). Keanekaragaman Spesies Ular di Desa Pering, Kecamatan Blahbatu, Kabupaten Karanganyar, Bali. Jurnal Biologi Udayana, 21(1), 7-11.

Chim, C. K. \& Diong, C. H. (2013). A Mark-Recapture Study of A Dog-Faced Water Snake Cerberus schneiderii (Colubridae: Homalopsidae) Population in Sungei Buloh Wetland Reserve, Singapore. Raffles Bulletin of Zoology, 61(2), 811-825.

CITES. (1983). Convention on Traditional Trade in Endangered Species of Wild Fauna and Flora. Retrieved from $h$ https://cites.org/sites/default/files/eng/ disc/CITES-Convention-EN.pdf.

Cromsigt, J. P., Prins, H. H. \& Olff, H. (2009). Habitat Heterogeneity as A Driver of 


\section{JURNAL BIDDJATI}

http://journal.uinsgd.ac.id/index.php/biodjati

Ungulate Diversity and Distribution Patterns: Interaction of Body Mass and Digestive Strategy. Diversity and Distributions, 15(3), 513-522.

Das, I. (2015). A Field Guide to The Reptiles of South-East Asia: Bloomsbury Publishing. Retrieved from https://3lib.net/ book/2883634/2a5f78.

Durso, A. M., Willson, J. D. \& Winne, C. T. (2013). Habitat Influences Diet Overlap in Aquatic Snake Assemblages. Journal of Zoology, 291(3), 185-193.

Hernowo, J. B., Priambodo, E. \& Siregar, S. (2007). Inventarisasi Keanekaragaman Fauna di Demosite Kawasan Mangrove Batu Ampar, Kalimantan Barat. Kerja sama Laboratorium Satwa Liar, Departemen Konservasi Sumberdaya Hutan dan Ekowisata, Institut Pertanian Bogor dengan Lembaga Pengkajian dan Pengembangan Mangrove Indonesia. Retrieved from https://repository.ipb.ac.id/ jspui/ bitstream/123456789/98660/1/3.\%20 Inventarisasi $\% 20$ Keanekaragaman $\% 20$ Fauna\%20di\%20Demosite\%20Kawasan $\% 20$ Mangrove $\% 20$ Batu $\% 20 \mathrm{Am}$ par\%2C\%20Kalimantan\%20Barat.pdf

Hidayah, A., Hanifa, B. F., Devi, S. R., Septiadi, L., Alwi, M. Z. \& Afifudin, F. A. (2018). Keanekaragaman Herpetofauna di Kawasan Wisata Alam Coban Putri Desa Tlekung Kecamatan Junrejo Kota Batu Jawa Timur. Prosiding Seminar Nasional Hayati, 6(1), 79-91.

Imron, M. A., Pudyatmoko, S., Subrata, S. A. \& Nurvianto, S. (2018). Asas-asas Pengelolaan Satwa Liar di Indonesia: Buah Pemikiran Prof. Djuwantoko. Yogyakarta: Gadjah Mada University Press.

Kamsi, R., Handayani, S., Siregar, A. \& Fredriksson, G. (2017). Buku Panduan Lapangan Amfibi dan Reptil Kawasan
Hutan Batang Toru (D. T. Iskandar Ed. 1 ed.). Medan (ID): Herpetologer Mania Publishing.

Kamsi, M. (2018). Survei Amfibi Reptilia di Provinsi Aceh, Pulau Sumatera. Pro siding Biotik, 5(1), 21-25.

Kurniawan, N., Priambodo, B., Nugraha, F. A. D., Maulidi, A. \& Kurnianto, A. S. (2017). Microhabitat Assessment of Mangrove Pit Viper Cryptelytrops purpureomaculatus in Restricted Mangrove Area, Dumai, Riau Province, Sumatera. Journal of Tropical Life Science, 7(2), 91-94.

Kurniawan, N., Firdaus, A. S., Nugraha, F. A. D., Maulidi, A. \& Kurnianto, A. S. (2018). Fishermen's Perspective On Herpetofauna: A Case Study From Kuala Tungkal, Tanjung Jabung Barat, Jambi. Journal of Tropical Life Science, 8(1), 228127.

Marlon, R. (2014). 107+ Ular Indonesia: Panduan Visual dan Identifikasi Lapangan (J. Surpriatna Ed. Vol. 1). Jakarta (ID): Indonesia Nature \& Wildlife.

Mong, R., \& Tan, H. H. (2016). Snakebite by The Shore Pit Viper (Trimeresurus purpureomaculatus) Treated with Polyvalent Antivenom. Wilderness Environ Med. 27(2), 266-270.

O'Shea, M. (2018). The Book of Snakes: A Life-Size Guide to Six Hundred Species from Around The World. USA: University of Chicago Press.

Pawlak, J., Mackessy, S. P., Fry, B. G., Bhatia, M., Mourier, G., Fruchart-Gaillard, C., ... \& Kini, R. M. (2006). Denmotoxin, A Three-Finger Toxin from The Colubrid Snake Boiga dendrophila (Mangrove Catsnake) with Bird-Specific Activity. Journal of Biological Chemistry, 281(39), 29030-29041. 


\section{JURNAL BIDDJATI}

http://journal.uinsgd.ac.id/index.php/biodjati

Partasasmita, R., Iskandar, J. \& Malone, N. (2016). Karangwangi People's (South Cianjur, West Java, Indonesia) Local Knowledge of Species, Forest Utilization and Wildlife Conservation. Biodiversitas: Journal of Biological Diversity, 17(1), 154-161.

Pratiska, I. G. P. A, Suaskara, I. B. M, Wiryatno, J. \& Putra, I. G. A. P. (2017). Inventarisasi Jenis-jenis Ular yang Ditemukan di Sekitar Pantai Merta Sari dan Padang Galak. Simbiosis, 5(2), 6972.

Roza, M., Hermon, D. \& Triyatno. (2018). Strategi Pengembangan Ekowisata Mangrove di Desa Rawa Mekar Jaya Kecamatan Sungai Apit Kabupaten Siak Provinsi Riau. Jurnal Buana, 2(4),
421-431.

Susanto, R. B., Yoza, D. \& Arlita, T. (2016). Potensi dan Daya Dukung Kawasan Ekowisata Hutan Mangrove Bandar Bakau Dumai. Disertasi. Riau University.

Wilhm, J. L. \& Dorris, T. C. (1968). Bio logical Parameters for Water Quality Criteria. Bioscience, 18(5), 477-481.

Yuliana, E., Hewindati, Y. T., Winata, A., Djatmiko, W. A. \& Rahadiati, I. A. (2019). Diversity and Characteristics of Mangrove Vegetation in Pulau Rimau Protection Forest, Banyuasin District, South Sumatra, Indonesia. Biodiversitas Journal of Biological Diversity, 20(4), 1215-1221. 